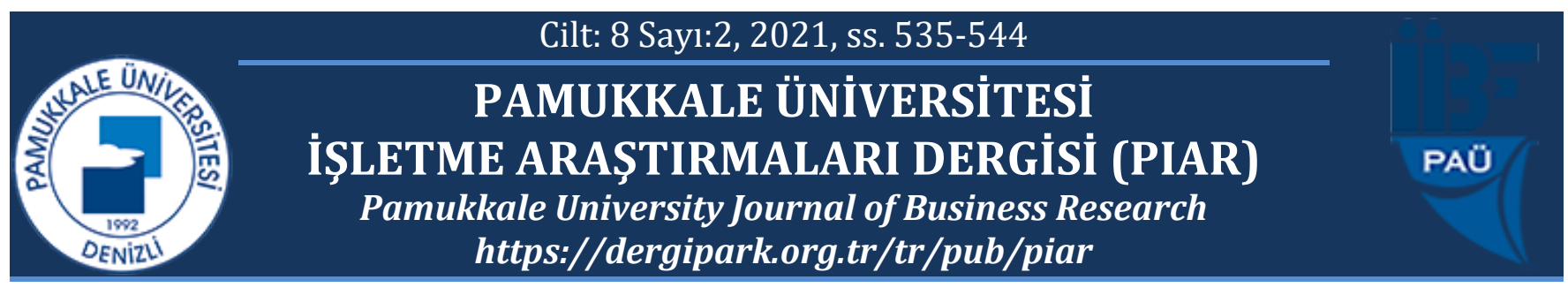

\title{
The Performance of Portfolio Management Companies in Terms of Pension Funds: Evidence from Turkey ${ }^{1}$
}

\author{
Portföy Yönetim Şirketlerinin Emeklilik Fonları Açısından Performansı: \\ Türkiye'den Kanıtlar
}

\section{Göksal Selahatdin KELTEN *}

\begin{abstract}
* Yazışılan Yazar/Corresponding author, Pamukkale University, Faculty of Economics and Administrative Sciences, gkelten@pau.edu.tr, https://orcid.org/0000-0002-7273-7613
\end{abstract}

Makale Geliş/Received: 12.11.2021

Makale Kabul/Accepted: 14.12.2021

\begin{abstract}
Private Pension System (PPS) which has been in practice for many countries began its operations on 27 October 2003 in Turkey, and Pension Fund Companies (PFCs), Portfolio Management Companies (PMCs), and government authorities are three main actors in the system. Evaluating the performance of pension funds is vital to the benefit of all participants. In addition, the performance of the relevant funds should be periodically reviewed to use financial resources effectively and efficiently. In this respect, private pension funds are of vital importance, especially for countries with a savings deficit such as Turkey. When the finance literature is examined, it is seen that there are many studies to measure fund performance. However, examining the performance of funds alone is not an adequate control method for the IPS. In addition to the performance of the funds, the performance of those who manage the funds is also important for economic development. In this context, the aim of the study is to evaluate the performance of the PMC of pension funds with Sharpe Ratio and Treynor Index. 149 funds managed by 12 PMCs were included in the analysis for the period between January 2013 and December 2016. According to the findings, TEB PMC has the highest average Sharpe ratio (0.0768) and QNB FINANS PMC has the lowest highest average Sharpe ratio (0.0225). According to the Treynor index, the highest average score (0.0524) belongs to GARANTI PMC while the lowest score belongs to YAPI KREDI PMC with (0.0048).
\end{abstract}

Keywords:: Private Pensions, Pension Funds, Portfolio Management Companies

JEL codes: J32
Öz

Birçok ülkede uygulanmakta olan Özel Emeklilik Sistemi (BES), Türkiye'de 27 Ekim 2003 tarihinde faaliyete geçmiş olup, sistemin üç ana aktörü Bireysel Emeklilik Şirketleri (PFC), Portföy Yönetim Şirketleri (PYŞ) ve devlet kurumlarıdır. Emeklilik fonlarının performansinın değerlendirilmesi, tüm katılımclların yararına hayati önem taşımaktadır. Ayrıca, finansal kaynakların etkin ve verimli kullanılması için ilgili fonların performansı periyodik olarak gözden geçirilmelidir. Bu açıdan bireysel emeklilik fonlarl, özellikle Türkiye gibi tasarruf açı̆̆ı olan ülkeler için hayati önem taşımaktadır. Finans literatürü incelendiğinde fon performansın ölçmeye yönelik birçok çalışmanın olduğu görülmektedir. Ancak tek başına fonların performansının incelenmesi BES için yeterli bir kontrol yöntemi değildir. Fonların performansinın yanı sira fonlar yönetenlerin performansı da ekonomik kalkınma için önemlidir. Bu bağlamda çalışmanın amacı, Sharpe Ratio ve Treynor Index'i ile emeklilik fonları yöneten PYŞ'lerin performansın değerlendirmektir. Ocak 2013 ile Aralık 2016 arasinda 12 PYŞ tarafindan yönetilen 149 fon analize dahil edilmiştir. Bulgulara göre ilgili dönemde TEB PMC en yüksek ortalama Sharpe oranına (0.0768) ve QNB FINANS PMC en düşük ortalama Sharpe oranına (0.0225) sahiptir. Treynor endeksine göre en yüksek ortalama (0.0524) GARANTI PMC'ye, en düşük skor (0.0048) ile YAPI KREDI PMC'ye aittir.

Anahtar Kelimeler: Özel Emeklilik, Emeklilik Fonları, Portföy Yönetim Şirketleri JEL kodlarn: J32

\footnotetext{
1 An early version of this article was presented at the 23rd Finance Symposium, 9-12 October in Antalya, and published on pages 925-939 of the proceedings book as "Evaluation of the Portfolio Management Companies in Terms of Pension Funds: Evidence from Turkey".
} 


\section{INTRODUCTION}

The aging of the population, the deterioration of the asset-liability balance, the increase in the costs of health services, the unnecessary interventions of politicians, economic fluctuations, inflation, unemployment, the tendency to employ uninsured workers have put social security systems in trouble in almost every country (Tuncay, 2000: 4). The increase in average life expectancy, and retirees to the working population ratios have increased over the world. In this case, it has become difficult to finance retirees with the premiums paid by the employees (Moral1, 2016: 21).

According to the Turkish Statistical Institute's (TurkStat) predictions shown in Fig.1, the population growth rate of the Turkey is decreasing while the average life expectancy at birth is increasing within the upcoming years. As well as other countries, Elderly dependency ratio reveals that the population is getting older and older, the number of workers is decreasing, and the retirees are increasing in Turkey.

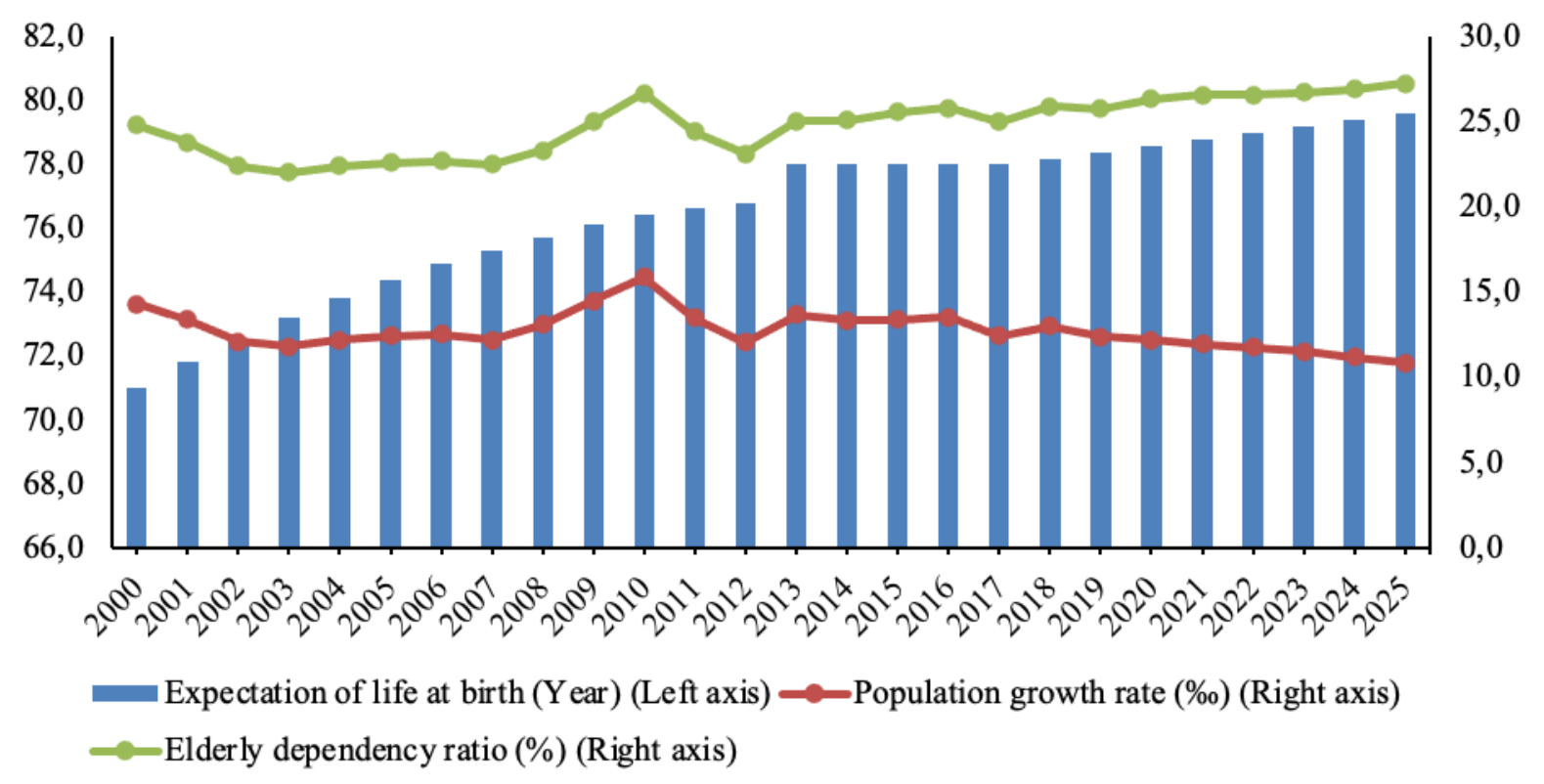

Fig. 1. Expectation of life at birth, Elderly dependency ratio, and Population growth rate in Turkey.

Source: TurkStat https://www.tuik.gov.tr/ (30.10.2021)

Private Pension System (PPS) is accepted as an alternative solution to financial problems in social security system and Chile is the first example in practice (Korkmaz et. al, 2007: 65). In Turkey, PPS went into operation on 27th October 2003 after the approvement of the "Individual Pension Savings and Investment System Act" in The Grand National Assembly of Turkey (GNAT) and Pension Fund Companies (PFCs), Portfolio Management Companies (PMCs) and government authorities are three main players of the system. The PPS in Turkey consists of two categories as voluntary participation (IPS) ${ }^{2}$ and auto enrolment system (AES).

\footnotetext{
${ }^{2}$ The first-time implementations of the private pension system in Turkey started on a voluntary basis. That's why the whole system is called as "Individual pension system". In this study, "PPS" stands for private pension system; "IPS" stands for voluntary participation.
} 
This study focuses on voluntary participation. As of 31 August 2021, there are 15 PFC and the total amount of the fund in the IPS is 152,33 billion TL.

Table 1. PFCs and IPS statistics in Turkey

\begin{tabular}{|l|r|r|r|r|r|}
\hline \multicolumn{1}{|c|}{ PFC } & \multicolumn{1}{c|}{$\begin{array}{c}\text { \# of } \\
\text { fund }\end{array}$} & \multicolumn{2}{c|}{ \# of Contributor } & \multicolumn{2}{c|}{$\begin{array}{c}\text { Total Premium } \\
\text { paid by Contributers (TL) }\end{array}$} \\
\hline Türkiye Hayat ve Emeklilik A.Ş. & 37 & 2022822 & $29.0 \%$ & 28716893642 & $18.9 \%$ \\
\hline AgeSA Hayat ve Emeklilik A.Ş. & 26 & 661024 & $9.5 \%$ & 27963514871 & $18.4 \%$ \\
\hline Anadolu Hayat Emeklilik A.Ş. & 24 & 1103640 & $15.8 \%$ & 27364847121 & $18.0 \%$ \\
\hline Allianz Yaşam ve Emeklilik A.Ş. & 17 & 725423 & $10.4 \%$ & 21823071360 & $14.3 \%$ \\
\hline Garanti Emeklilik ve Hayat A.Ş. & 19 & 1112820 & $16.0 \%$ & 21582360180 & $14.2 \%$ \\
\hline NN Hayat ve Emeklilik A.Ş. & 11 & 254023 & $3.6 \%$ & 5461144402 & $3.6 \%$ \\
\hline Allianz Hayat ve Emeklilik A.Ş. & 9 & 86620 & $1.2 \%$ & 4906278084 & $3.2 \%$ \\
\hline BNP Paribas Cardif Emeklilik A.Ş. & 10 & 177036 & $2.5 \%$ & 3668941740 & $2.4 \%$ \\
\hline Katılım Emeklilik ve Hayat A.Ş. & 9 & 327172 & $4.7 \%$ & 3403460023 & $2.2 \%$ \\
\hline Fiba Emeklilik ve Hayat A.Ş. & 29 & 90079 & $1.3 \%$ & 2694701060 & $1.8 \%$ \\
\hline Metlife Emeklilik ve Hayat A.Ş. & 9 & 186250 & $2.7 \%$ & 2331951752 & $1.5 \%$ \\
\hline Cigna Sağlık Hayat ve Emeklilik A.Ş. & 11 & 66165 & $0.9 \%$ & 908995689 & $0.6 \%$ \\
\hline Axa Hayat ve Emeklilik A.Ş. & 7 & 32630 & $0.5 \%$ & 752031847 & $0.5 \%$ \\
\hline Bereket Emeklilik ve Hayat A.Ş. & 6 & 84452 & $1.2 \%$ & 618957817 & $0.4 \%$ \\
\hline Aegon Emeklilik ve Hayat A.Ş. & 4 & 35551 & $0.5 \%$ & 136707794 & $0.1 \%$ \\
\hline Total & 228 & 6965707 & $100 \%$ & 152333857382 & $100 \%$ \\
\hline
\end{tabular}

Source: Pension Monitoring Center https://www.egm.org.tr/ (30.10.2021)

IPS may have positive impacts on financial markets and economic development by creating long-term resources (Uyar, 2012: 73). So, IPS should be monitored closely, and the performance of the funds should be observed periodically to ensure the effectiveness and efficiencies of financial resources and to protect participants' benefits.

The rest of this paper is organized as follows. In the next section, related literature of the topic is provided. The data and research methodology of this paper are explained in the third section. Section four presents the findings, and the last section is dedicated to conclusion.

\section{THEORETICAL BACKGROUND}

Portfolio management has gained importance after Harry Markowitz's study called "Portfolio Selection" in 1952. It is possible to divide Portfolio-related studies into two groups as pre- and post-Markowitz because Markowitz has brought a new dimension to whole portfolio management. The general logic of "not putting all the eggs in the same basket" has changed and the relationship between financial instruments has begun to be considered when creating a portfolio. After his study, performance of funds and portfolios are gained importance and there have been a lot of studies were conducted on portfolio selection, portfolio management, measurement of funds and portfolio performances.

Over time, many researchers have tried to measure portfolio and fund performance. From these studies, Treynor (1965), Sharpe (1966) and Jensen (1968) are important for leading the 
other studies. Treynor developed a performance measurement for fund-management in 1965. In 1966 Sharpe generated reward-to-volatility-ratios (Sharpe Ratio) and investigated the annual return of thirty-four mutual funds. The study conducted for the period between 1954 and 1963 and the performance of these funds compared with the performance of DowJones Index. According to the empirical results while there are eleven funds were successful than the Index, twenty-three funds were worse than the benchmark. Jensen (1968) also generated a different performance measurement which is called as "Jensen's alpha" and investigated 115 mutual funds for the 1945-64 period. According to the results only 39 funds had positive alpha values and the author concludes that the mutual funds didn't have performance well enough.

There are numerous articles that focus on pension fund investments. Some of these studies are as follows. Reece and Sam (2012) investigated the impact of pension privatization on foreign direct investment and indicated that privatization triggers a significant increase in FDI. Ayaydin (2013) tries to examine pension funds' managers' market success. Author investigates 34 pension funds operating between 2010-2013 in Turkey and the low performance of the funds were connected with the managers' ability to understand of the changes in market conditions. Selim and Çelik (2014) investigate the determinants of individual pension funds for 32 OECD countries with panel regression analysis. They analyse the 2005-2011 period and according to the results household consumptions, gross domestic product per capita and the average retirement age of men had significant negative effect on individual pension funds while population, health expenditures and employment had positive effects.

Gökçen and Yalçın (2015) analysed Turkish pension funds for the period January 2004December 2011. They state that most of the active managers were not able to provide performance beyond what could be achieved by passive indexing. According to the results of the study, they concluded that pension plan contributors would be much better served with lower-cost passive alternatives than to active funds available. Jackwerth and Slavutskaya (2016) investigated the U.K. pension funds with manipulation proof performance measure of Goetzmann et al. (2007). They sought an answer to the question of what could be achieved if $10 \%$ of the investment, which invested entirely of pension funds, was invested in hedge fund. They state that this strategy improves the annual performance of pension funds. Broeders et al. (2016) investigated 225 Dutch pension funds using 2013 data. According to the results they stated that there is a significant negative relation between investment costs and pension fund size. They also indicate that large pension funds profit from economies of scale.

There is a direct state contribution of $25 \%$ of the personal contribution to increase the number of participants that has been applied in Turkey since 2013. Ertuğrul et al. (2018) aimed to analyse the effect of the direct state contribution on the number of participants. They concluded that the direct state contribution was successful in increasing the number of participants. Another study was conducted by Broeders et al. (2019) on 218 Dutch occupational pension funds. They analysed the relation between investment returns and performance fees from 2012 to 2017. According to statistical results, the returns of pension funds that pay performance fees to their asset managers for active investing are not significantly different from the pension funds that do not pay performance fees. ChavezBedoya and Castaneda (2021) proposed a methodology for comparing the impact of 
administrative fees on individual welfare and recommended it to institutions and regulators as a benchmarking tool to monitor the behaviour of administrative fees in different defined contribution pension systems.

\section{AIM AND SCOPE OF THE STUDY}

This paper aims to examine the performances of each PMC with Sharpe Ratio and Treynor Index in Turkey. Within the scope of the paper, 12 PMCs which manage at least five IPFs were considered. Totally, 149 IPFs managed by the same PMC between the dates of 01.01.2013 and 31.12.2016, are included in the analysis. Therefore, mergers, acquisitions, passive and liquidated IPFs were excluded from the analysis. The PMCs and number of IPFs included in the analysis are given in Table 2.

Table 2. PMCs and \# of IPFs in the Analysis

\begin{tabular}{|c|c|c|}
\hline & Name of the PMCs & \# of IPF \\
\hline $\mathbf{1}$ & AK PMC & 26 \\
\hline $\mathbf{2}$ & DENIZ PMC & 7 \\
\hline $\mathbf{3}$ & GARANTI PMC & 16 \\
\hline $\mathbf{4}$ & HALK PMC & 5 \\
\hline $\mathbf{5}$ & HSBC PMC & 13 \\
\hline $\mathbf{6}$ & ING PMC & 8 \\
\hline $\mathbf{7}$ & IS PMC & 24 \\
\hline $\mathbf{8}$ & QNB FINANS PMC & 7 \\
\hline $\mathbf{9}$ & TEB PMC & 8 \\
\hline $\mathbf{1 0}$ & VAKIF PMC & 13 \\
\hline $\mathbf{1 1}$ & YAPI KREDI PMC & 16 \\
\hline $\mathbf{1 2}$ & ZIRAAT PMC & 6 \\
\hline Total & & $\mathbf{1 4 9}$ \\
\hline
\end{tabular}

\section{DATA AND METHODOLOGY}

The performance measurement technique must consist of risk and return of the related financial instrument. Although all techniques are based on these two variables, there are some differences between them. The most important difference comes from logic of the risk measurements. According to risk measurement, it is possible to divide traditional performance measurement techniques into two groups as standard deviation based and systematic risk based. While Sharpe ratio, Sortino ratio and MSquare are based on standard deviation; Treynor Index and Jensen alpha are based on systematic risk. Since the risk criteria of both groups are different, the rankings of the funds may also differ. In this paper, Sharpe ratio, which is based on standard deviation, and Treynor Index which is based on systematic risk were calculated for each IPF. Thus, the performance of the PMCs can be seen according to both risks and the two rankings can be compared.

In order to calculate performance measurements, the daily return of IPFs, the daily market return and risk-free rate are needed. These data were gathered from database of The Capital Markets Board of Turkey (daily values of IPFs) and the Bloomberg terminal ( $\mathrm{rf}$ and $\mathrm{rm}$ ) for the 2013-2016 period. PMC information of the IPFs were achieved the from their annual 
audit reports. The audit reports were obtained from Public Disclosure Platform (PDP) of Turkey.

Computing the daily returns of individual funds and market (XU100) index with the formula (1) (Yıldırım and Çolakyan, 2014: 12) is the starting point of the analysis.

$r_{i t}=\ln _{V i_{t}}-\ln _{V i_{t-1}}$

$r_{i t} \quad$ : return of $i$ on $t$

$\ln _{V i_{t}} \quad$ : value of $i$ on $t$

$\ln _{V i_{t-1}}:$ value of $i$ on $t-1$

After the calculation of daily return, the averages and standard deviations of these returns are calculated with the formula (2), (Yıldırım and Çolakyan, 2014: 16).

$\sigma_{r_{i}}=\sqrt{\sum_{t=1}^{n}\left[r_{i t}-\bar{r}_{i}\right]^{2}} / \mathrm{n}$

$\sigma_{i t} \quad$ : standard deviation of $i$

$r_{i t} \quad$ : return of $i$ on $t$

$\bar{r}_{i} \quad$ : average return of $i$

Average returns and standard deviation of each IPFs are illustrated on Fig. 2. respect to their PMCs.

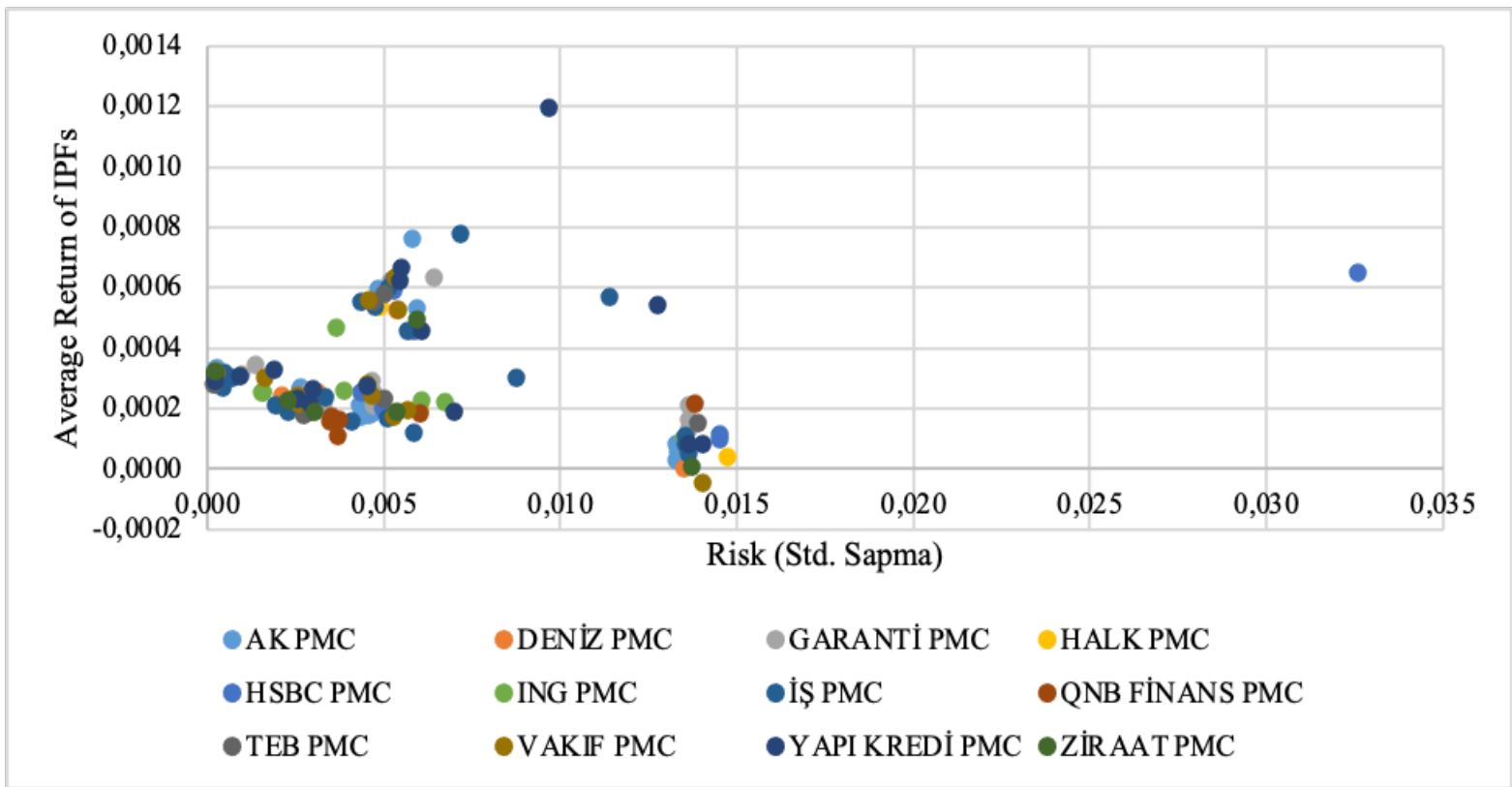

Fig. 2. Average Returns and Std. Deviations of IPFs

In this paper, Sharpe Ratio which is based on standard deviation and Treynor Index which is based on systematic risk were calculated for each IPF. The measurement formulas used in the study are as follows (3), (4) (Korkmaz and Uygurtürk, 2007: 41). 


\begin{tabular}{|c|c|c|}
\hline Sharpe Ratio & $\frac{r_{i}-r_{f}}{\sigma_{r_{i}}}$ & $\begin{array}{c}\text { ri: return of } i \\
\text { rf: risk free rate } \\
\sigma_{r i}: \text { standard deviation of } i\end{array}$ \\
\hline Treynor Index & $\frac{r_{i}-r_{f}}{\beta_{i}}$ & $\begin{array}{c}\text { ri: return of } i \\
\text { rf: risk free rate } \\
\beta_{i} \text { : Beta coefficient of } i\end{array}$ \\
\hline
\end{tabular}

\section{FINDINGS}

Within the scope of the paper, 12 PMCs which manage at least five IPFs are considered. Totally, 149 IPFs which managed by the same PMC between the dates of 01.01.2013 and 31.12.2016, are included in the analysis. In this study, after finding the Shape ratio and Treynor index of IPFs, they were divided into 12 groups according to their PMCs. As the final stage of the analysis, the average of each PMC was calculated, and they were ranked from largest to smallest which shown in Fig. 3. and Fig. 4. to understand their relative performance over the sampling period.

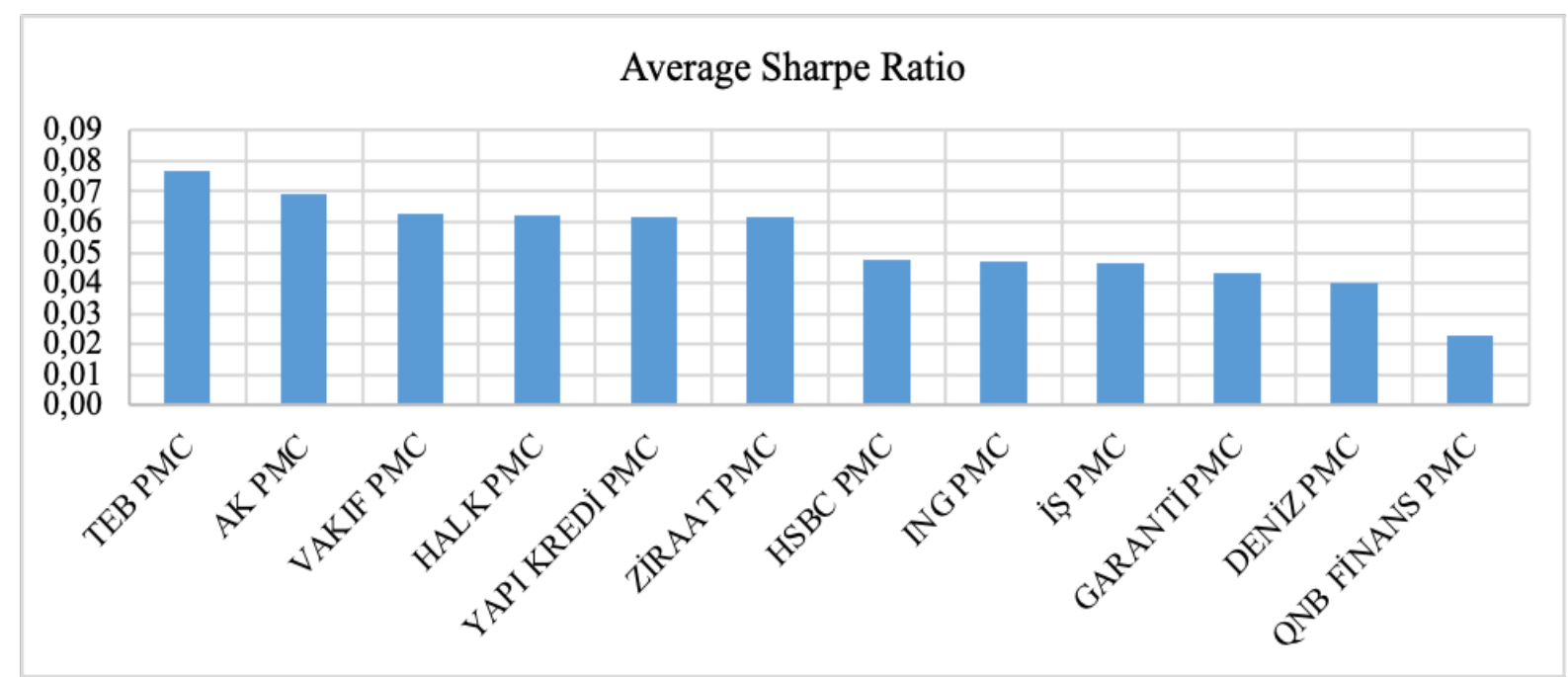

Fig. 3. Average Sharpe Ratios of PMCs 


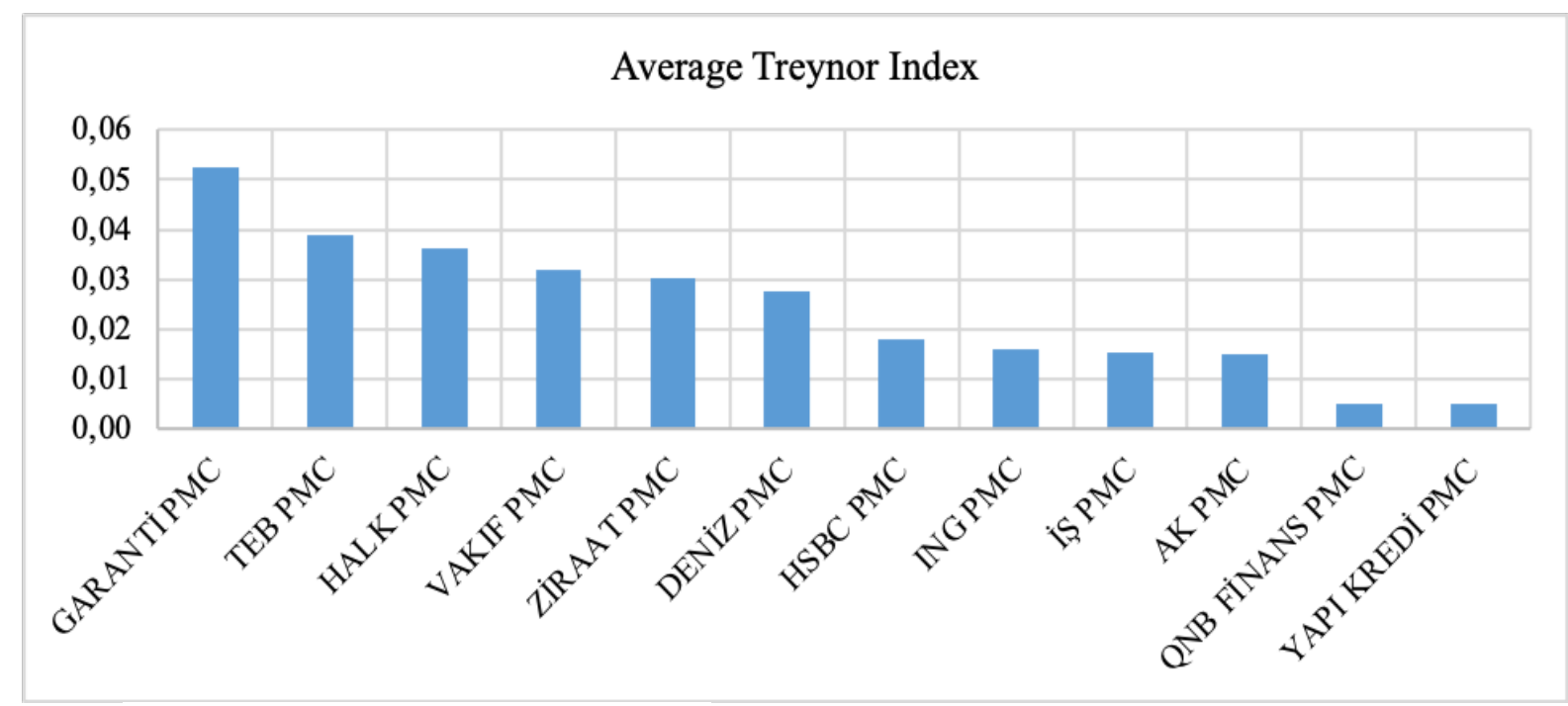

Fig. 4. Average Treynor Indexes of PMCs

\section{CONCLUSION}

In the finance literature, there are a lot of studies dealing with fund performance, although studies related to the performance of the management companies holistically are limited. Therefore, in this study, portfolio management companies operating in Turkey are evaluated with a holistic approach in terms of the pension funds they manage. This paper tries to shed lights on the performance of IPFs and their PMCs. With the scope of the analysis 149 IPFs managed by 12 PMCs were included for the 2013-2016 period. TEB PMC has the highest average Sharpe ratio (0.0768) and QNB FINANS PMC has the lowest average Sharpe ratio with (0.0225). According to the Treynor index the highest average score $(0.0524)$ belongs to GARANTI PMC while lowest score belongs to YAPI KREDİ PMC with (0.0048). Those who invest in the pension fund can access the information on who manages the fund they invest in. It is expected that they will benefit from the analyses outputs while making their investment decisions. The other outcomes of the study may be summarized as follows; First, PFCs may choose the best performed PMC to manage their pension funds. Secondly, the PMCs also have an opportunity to understand their own positions and to compare their position with competitors. Another benefit of this article is that it provides useful information for authorities to monitor the performance of the whole IPS. In future studies, the determinants of these performances (management fee, portfolio size, firm's experience, number of funds, number of managers etc.) can be examined. 


\section{REFERENCES}

Ayaydın, Y. H. (2013). Türkiye'deki Emeklilik Yatırım Fonlarının Performanslarının Analizi. Çukurova Üniversitesi Sosyal Bilimler Enstitüsü Dergisi. 22(2). 59-80.

Broeders, D. W., van Oord, A., \& Rijsbergen, D. R. (2016). Scale economies in pension fund investments: A dissection of investment costs across asset classes. Journal of International Money and Finance. 67. 147-171. doi: 10.1016/j.jimonfin.2016.04.003

Broeders, D. W., van Oord, A., \& Rijsbergen, D. R. (2019). Does it pay to pay performance fees? Empirical evidence from Dutch pension funds. Journal of International Money and Finance. 93. 299-312. doi: 10.1016/j.jimonfin.2019.02.010

Chavez-Bedoya, L., \& Castaneda, R. (2021). A benchmarking approach to track and compare administrative charges on flow and balance in individual account pension systems. Insurance: Mathematics and Economics. 97. 7-23. doi: 10.1016/j.insmatheco.2020.12.006

Ertuğrul, H. M., Gebeşoğlu, P. F., \& Atasoy, B. S. (2018). Mind the gap: Turkish case study of policy change in private pension schemes. Borsa Istanbul Review. 18(2). 140-149. doi: 10.1016/j.bir.2017.11.003

Goetzmann, W., Ingersoll, J., Spiegel, M. \& Welch, I. (2007). Portfolio Performance Manipulation and Manipulation-proof Performance Measures. The Review of Financial Studies. 20(5). 1503-1546, doi: 10.1093/rfs/hhm025

Gökçen, U., \& Yalçın, A. (2015). The case against active pension funds: Evidence from the Turkish Private Pension System. Emerging Markets Review. 23. 46-67. doi: 10.1016/j.ememar.2015.04.007

Jackwerth, J. C., \& Slavutskaya, A. (2016). The total benefit of alternative assets to pension fund portfolios. Journal of Financial Markets. 31. 25-42. doi: 10.1016/j.finmar.2016.06.002

Jensen, C. M. (1968). The Performance of Mutual Funds in the Period 1945-1964. The Journal of Finance. 23(2). 389-416. doi: 10.1111/j.1540-6261.1968.tb00815.x

Korkmaz, E., Akgeyik, T., Yilmaz, B. E., Oktayer, N., Susam, N., \& Seker, M. (2007). Sosyal Güvenlikte Yeni Yaklaşım: Bireysel Emeklilik. İstanbul: İstanbul Ticaret Odası Yayınları. Yayin No: 2006-21.

Korkmaz, T. and Uygurturk, H. (2007). Using Regression Analysis in Turkish Pension Funds' Performance Measurements. ZKU Sosyal Bilimler Dergisi. 3(5). 37-52.

Markowitz, H. (1952). Portfolio Selection. The Journal of Finance. 7(1). 77-91. doi: 10.1111/j.1540-6261.1952.tb01525.x

Moralı, T. (2016). Bireysel emeklilik sistemi yatırımcularının davranışsal tercihlerini etkileyen faktörlerin yapısal eşitlik modeli ile analizi. Unpublished Dr. thesis. Pamukkale 
Üniversitesi, SBE. [Retrieved from https://tez.yok.gov.tr/UlusalTezMerkezi/] (30.10.2021).

Reece, C., \& Sam, A. G. (2012). Impact of pension privatization on foreign direct investment. World Development. 40(2), 291-302. doi: 10.1016/j.worlddev.2011.06.003

Selim and Celik (2014). The Determinants of Individual Pension Funds: The Case of OECD. The Journal of Social and Economic Research. 14(28). 188-208. doi: 10.30976/susead.302207

Sharpe, W. (1966). Mutual Fund Performance. The Journal of Business. 39(1). 119-138. [Retrieved from http://www.jstor.org/stable/2351741] (15.10.2021).

Treynor, J. (1965). How to rate management of investment funds. Harvard Business Review. 43(1). 63-75.

Tuncay, A. (2000). Bireysel Emeklilik Rejimi Üzerine. Çimento İşveren Dergisi, 2(14). 3-16.

Uyar, H. (2012). The investigation of relationship between private pension system and the economic indicators. Financial Analysis. 22(10). 71-94.

Yıldırım, H., \& Çolakyan, A. Finansal Yatırım Araçlarında Riske Maruz Değer Uygulaması. Dokuz Eylül Üniversitesi İktisadi İdari Bilimler Fakültesi Dergisi, 29(1), 1-24. 